\title{
Política Tributária e Nordeste
}

\author{
Geraldo Ataliba \\ Professor Adjunto do Departamento \\ de Direito Econômico e Financeiro
}

\section{a) Preliminares}

O sistema tributário brasileiro é tecnicamente um dos mais perfeitos do mundo. Basta compará-lo com o italiano, recentemente reformado (1974), ou com o espanhol (1977) e já se vê a sua superioridade formal. É mais objetivo, mais claro, mais racional. Tem virtudes jurídicas, econômicas e políticas evidentes. É rígido juridicamente, sem o ser do ponto de vista econômico. É fruto de uma evolução, que deita raizes na Constituição de 1891, mas foi conscientemente sendo aprimorado.

Pensamos que o Brasil pode assistir ao cotejo de seu sistema tributário com o de muitos países adiantados, sem correr o risco de envergonhar-se, embora muito ainda falte para que seu funcionamento efetivo corresponda a todas as postulações sistêmicas. Os progressos de que nos temos revelado capazes, porém, são animadores, como indícios de nossa capacidade de auto-aprimoramento.

É um sistema que se pode qualificar de tecnicamente evoluído. Em matéria de discriminação de competências, fixação de princípios e adoção de critérios jurídicos de classificação geral dos tributos e categorização de subespécies tributárias (pela materialidade das hipóteses de incidência), estamos certamente à frente de todos os demais países, de modo geral.

Surpreende, pois, que no nosso arsenal tributário não tenhamos ainda instituído dois eficientes instrumentos de política fiscal, dirigidos à redistribuição de riquezas e estabilização social.

Referimo-nos aos impostos sobre ganhos de capital e sobre o patrimônio.

Ambos, pelo teor da Constituição, se compreenderiam na competência residual da União ( $\$ 1^{\circ}$ do artigo 18 e $\S \S 1^{\circ}$ e $5^{\circ}$ do artigo 21 ).

Esses eficazes instrumentos podem - se bem manipulados pelo legislador federal - não só propiciar, a médio prazo, redistribuição 
de riqueza, como ainda servir de alavanca ao desenvolvimento regional, segundo sejam manipulados.

Parece-nos merecer prioridade o Nordeste, pelo clima social préexplosivo, decorrente do grande contingente populacional lá sediado.

Não se ignora que a Amazônia precisa ser ocupada e desenvolvida, até por uma questão de segurança nacional, dada a cobiça internacional, confessada na ONU, já em 1946. Mas, de nada vale manter a Amazônia e ver perecer o Nordeste.

Assim sendo, parece-nos ser oportuno e útil criar esses dois impostos, destinando, por um prazo certo - por exemplo: 10 anos o produto de sua arrecadação ao incentivo às indústrias que aproveitam produtos primários do Nordeste; às indenizações para desapropriação para fins de reforma agrária naquela área e outras atividades econômicas que absorvam mão-de-obra local.

\section{b) Imposto Sobre Ganhos de Capital}

Deve ser hipótese da incidência desse imposto (tributo não vinculado a uma atuação estatal) o que os ingleses chamam UNEARNED INCREMENT (incremento não ganho). Isto é: o aumento de capital não decorrente de atividade produtiva do seu titular, tais como: ganhos de bolsa; lucro imobiliário; valorização imobiliária oriunda de causas genéricas; ganhos cambiais e investimentos financeiros excepcionalmente rentáveis (assim entendidos os que superam a soma da correção monetária com os juros legais).

Note-se que tais ganhos não passam a ser ilícitos. Apenas serão tributados, como meio de fazer a coletividade partilhar os benefícios de resultados que se tornaram possíveis, graças a um contexto socia] propiciado por essa mesma coletividade.

\section{c) Imposto Sobre o Patrimônio}

A hipótese de incidência desse imposto deve ser o fato de uma pessoa (física ou jurídica) deter um certo patrimônio global. A alíquota deve ser moderada, mas suficiente para permitir que a coletividade - por seus extratos mais sofridos - de algum modo participe de um resultado só possível graças a um clima, uma situação, um contexto, de que certamente ela é fator conspícuo.

\section{d) Considerações Gerais}

Não se diga que esses impostos são "socializantes" ou agressivos à iniciativa privada. Eles existem em quase todos os países capitalistas do mundo. Vêm sendo aprimorados, aperfeiçoados e apurados com o evolver dos anos. 
E nossa tarefa estudar sua aplicação nos diversos países, conhecer seus aspectos positivos e negativos e tentar identificar seus defeitos de funcionamento.

Aí está grata e magna tarefa para economistas, financistas e juristas realizarem, de mãos dadas, tendo em vista o bem do Brasil, que hoje significa o desenvolvimento do Nordeste, o grande desafio posto à nossa geração.

A objeção que se pode levantar contra essa proposta está em que é recomendável que o produto de impostos, que atingem o capital, seja aplicado em benefício direto das áreas onde esse capital se localiza, até como fómula para desenvolvê-lo e incrementá-lo.

Não se nega a validade do princípio. Apenas se assinala que, no caso, se cuida de fixação de prioridades, tendo em vista interesses maiores da coletividade.

Além do que, só pode beneficiar o capital estabelecido a expansão do emprego em áreas densamente povoadas e a plena ocupação de mão-de-obra, onde já haja expressão demográfica.

Os maiores beneficiados, com a incorporação definitiva dos trinta milhões de nordestinos ao mercado consumidor nacional, serão os produtores dos bens requeridos por esse processo e das mercadorias a serem consumidas por essa população.

O mecanismo a ser criado funcionará como um investimento de grato retorno, para todos os contribuintes desses impostos.

\section{e) Contribuição de Melhoria}

A instituição desses impostos viria tornar quase perfeito o nosso sistema tributário, eliminando suas deficiências, consistentes nessas duas graves lacunas.

Resta dizer que urge - para que tal asserto não seja gratuito e de mero efeito retórico - fazer eficaz o instituto da contribuição de melhoria, tributo que onera as valorizações imobiliárias decorrentes de obras públicas (já previsto na Constituição).

Há uma comédia de equivocos, em torno desse tributo, o que vem impedindo boa legislação e correta aplicação.

Não só é imperioso corrigí-la (à legislação) — e torná-la idônea à obtenção das finalidades de que é a contribuição de melhoria instrumento - como importa prever meios e modos de coordená-la e harmonizá-la com o imposto federal sobre ganhos de capital. Para tanto é necessário prever a não cumulação de um e de outro.

O imposto grava todos os incrementos patrimoniais (genericamente considerados) não causados pelo titular do patrimônio. 
Essa contribuição onera o aumento de valor imobiliário que tenha por causa obra pública (especificamente considerada).

Parece importante fazer deduzir a contribuição de melhoria paga, do débito, a título de imposto sobre ganhos de capital, a fim de evitar flagrante bis in idem.

Por outro lado, como, no Brasil, já estamos bastante familiarizados com os mecanismos de correção monetária, penso que não será difícil estabelecê-los no respeitante, quer à contribuição de melhoria, quer aos impostos novos que se sugere criar.

A técnica, entretanto, tem que ser sensivelmente simplificada, para fazer-se acessivel a qualquer contribuinte.

É indiscutível que a dramática economia do Nordeste requer medidas corajosas para sua superação.

A adoção dos impostos aqui mencionados e o aprimoramento da contribuição de melhoria são medidas corajosas que se impõem.

A destinação, por alguns anos, do produto da arrecadação dos referidos impostos ao Nordeste seria ato de inquestionável, embora tardia, justiça. 